\title{
Café in small towns: A picture of the weakening social engagement
}

\author{
Nino Viartasiwi ${ }^{1}$ (D) Agus Trihartono² (D)
}

\begin{abstract}
${ }^{1}$ Ritsumeikan University, Institute of International Relations and Area Studies/IIRAS, Tojiin-Kitamachi, Kita-ku, Kyoto, Japan ${ }^{2}$ University of Jember, Center for Research in Social Sciences and Humanities/C-RiSSH, Jawa Timur, Indonesia

Contact authors: viartasiwinino@gmail.com, atrihartono@unej.ac.id

Received in November 27, 2019 and approved in March 10, 2020
\end{abstract}

\section{ABSTRACT}

Small towns in developing countries are grappling with the evolving global brand and modern coffee shops (cafés) that have driven out the traditional coffee shop. New cafés have also encouraged a global coffee culture with its uniformity of coffee presentation and quality standard. This research was conducted in East Java, Indonesia, from 2017 to 2018. This study analyses the changing of coffee culture from the perspective of coffee shops culture in small towns of the developing country. Previously, coffee shops served not only as community meeting spots but also as centres of information and resource exchanges. Coffee shop helped to mediate people's social interactions. Newly arrived café leaves the social dimension of the traditional coffee shop with limited interaction among its patrons. Café becomes a mere economic establishment and a token of a modern lifestyle. The study reveals that even though cafés improve the economy, the change reflects the changing of civic-bond in society. It concludes that the changing of coffee consumption in rural Indonesia may not only signing the arrival of a globalised coffee culture but also, signing the change of social engagement of the society.

Key words: Coffee for health; coffee culture; globalization; social engagement.

\section{INTRODUCTION}

Coffee helps in forming the global culture. Coffee is produced in developing countries but consumed more by people in industrialized countries. Brazil is the world's largest coffee producer (Cecilia et al., 2016) and the other top three coffee producers in the world are Vietnam, Columbia, and Indonesia, while European Union, Japan, Norway, and Russian Federation are the four biggest consumers (Torok; Mizik; Jambor, 2018). Coffee culture has been part of the cultures in those producer countries that are developing countries. However, the global coffee culture is formed in the industrialized countries by business players for its economic potential. The markers of global coffee culture are the standardization in quality of the beans and the roasting method, the same recipes on styling coffee, the similarity of coffee presentation, and the market's construction of coffee as an urban lifestyle that embodied in café culture.

Coffee may also shape and affect society. The research of Ferreira (2017), for instance, provides an overview and highlights some aspects of coffee and the mushrooming cafe industry in the UK. The work investigates social change, and also new economic geography has silently but significantly affected the refashioning of the cafe industry and the standard. The study also provided typologies and categories of cafes in providing coffee and how the cafe industry can be applied in various communities. Another study in developed country communities shows that enjoying coffee in the cafe may spillover to other activities. Thus, the cafe turns into one of the community's epicenters of activities. While enjoying coffee, society use cafe as an alternative place for chatting, writing, and even caring for babies. Thus, the cafe has shifted to a somewhat "autonomous organism" (Henriksen; Skjølsvold; Grønning, 2013) and new corner for "supportive physical environment" in the community (Broadway; Legg; Broadway, 2018). In a similar vein, another study has underlined the benefits of coffee for health (Dewanti et al., 2019; Esquivela; Jiménezb, 2012). Coffee beverage and the side products (i.e. coffee cherry flour and cascara) comprises many antioxidants, which affects good health for the human body (Damat et al., 2019; Esquivela; Jiménezb, 2012; Heeger et al., 2017; Vignoli; Bassoli; Benassi, 2011). Thus, café may also contribute to health-seeking issue in society. In short, cafés and coffee have many facets of the social dynamics of society.

In the context of developing country societies, domestic coffee cultures of coffee producer countries are connected with the character of its society. Taking Indonesia as an example, coffee has been widely consumed with a variety of styles and traditions. Coffee is not only the favorite national beverage but also bearing a social function that is marked by the existence of coffee shops (Rahma; Farida; Marifatullah, 2019). Patronized mostly by the male, the coffee shop also serves as an informal community meeting spot, more than a place to enjoy coffee (Erman, 2014; Gumulya; Helmi, 2017). The establishment reflects the characteristics of Indonesian agricultural culture that are communal. They are a group of people that mostly prioritizes common interests and emphasizes that community needs are more important than individual interests. Indonesian recognize a principle called Gotong Royong (mutual cooperation) to represent commonality. It reflected how all patrons engage in free public-discussions regardless of their social class. 
Domestic coffee cultures in coffee producer countries are now in the process of changing due to the arrival of more modern coffee shops, known as café. In Indonesia, the growing economy has encouraged rapid café expansion. In 2016, around 10000 cafés were estimated in the business in Indonesia, with predicted total revenue to be around USD $4.16 \times 10^{6}$ in 2018 (JPNN, 2016). International coffee shop chains are also flowing the market. Local coffee shops started to imitate the style of coffee shops in developed countries. The first to change were coffee shops in big cities. Gradually, coffee shops in small towns follow the trend. Inevitably, the changing of the coffee shop's business model is also changing the domestic coffee culture.

Drawing from the phenomenon of the development of the coffee industry in Indonesia-the coffee production and coffee consumption-the study seeks to reveal the impact of the development on the society at large. The study identifies changes that new coffee shops bring to small towns in Indonesia and link the changes in coffee culture with social change in society. The research answers the questions of, first, how does the current situation of the coffee shop, and how does it encourage the changing of the coffee culture of the people? Second, how does the change in coffee culture reflect the change in the social engagement of the society?

\section{MATERIAL AND METHODS}

\subsection{Method}

This study describes the shifting behaviors of the coffee shop patrons from the traditional coffee shop to the modern café. It provides the contextual analysis of the occurrence by using qualitative research as the primary method and survey as the baseline.

The qualitative research is used as the primary method because the method is better in capturing human behavior by understanding opinions, feelings, attitudes, and perceptions of a topic. According to Bloor and Wood (2006), the qualitative method allows the researcher to use rapid assessment techniques to deepen the context and the meaning of the data. A variety of data collecting that goes beyond a format of question and answer is also possible in this method (Sutton; Austin 2015). Data collection was conducted through interviews with keyinformants with semi-structured questions. Interviews were conducted to 27 people (20 males, seven females) in 2018 from several small towns in East Java, namely: Bondowoso District, Jember District, Banyuwangi District, Lumajang District, Malang District, Gresik District, Lamongan District, Ngawi District, Bojonegoro District, Blitar District and Tulungangung District. The consideration behind choosing the areas are: First, those districts are in the classification of small towns. In Indonesia, there are two kinds of areas, namely city and district.
The later (district or Kabupaten) are considered as small towns. Second, cafés have been mushrooming in those small towns.

The baseline study uses a quantitative method through a survey on coffee culture in society. The data taken from the survey is on the demography of coffee consumers, coffee consumption behavior against the personal income and age categories, and general coffee consumption habit. The survey was conducted by Pilar Data Research and Consulting in March 2017 with a multistage random sampling method. The survey's population is Indonesian. The randomly selected respondents were taken proportionally from all districts in East Java Province, were above 17 yr or has married, genderbalanced, and were interviewed with face-to-face interview techniques, close-ended questions. Out of the whole 220 respondents, 200 respondents' samples were verified.

\subsection{Organization of the discussion}

First, this paper explains the baseline study that is to find out who are the coffee consumers based on individual income and age against their coffee habitual. Second, using descriptive analysis, the study observes the changes in coffee shops' service and customer behavior changes. The discussion emphasizes the current situation of the behavior of the coffee shops' patrons, the coffee shop business, and the customers' engagement.

\section{RESULTS}

\subsection{Baseline study}

The survey reveals that $79.4 \%$ of East Java adult populations are coffee consumers. The table below shows further profiles (in percentage) of the coffee consumers. On the monthly income base, the survey questionnaire uses Indonesian income rate as the scale and Indonesian currency (Rupiah/IDR) that is converted to USD in the Table 1.

Based on the survey's data, further research was conducted with the qualitative method through in-depth interviews to see the change in the coffee culture and café development. The interviewees and members of FGDs are those under the categories of minimum individual's monthly income of USD 35 and above 26 yr. The selection is based on the convergence between the consumerism of coffee with drinking frequency and the drinking place, as shown in the Table 1 .

\subsection{The change}

From interviews and FGD, the study found that respondents' habit to visit café has been growing in the last $6 \mathrm{yr}$, following their growing awareness to coffee quality and increase in individual income. Most respondents visited café for the first time at around 2011 to 2012 following their 
Table 1: Profiles of coffee consumers in East Java Province, Indonesia.

\begin{tabular}{|c|c|c|c|c|c|c|c|c|}
\hline & \multicolumn{4}{|c|}{ By Individual Monthly Income (USD) } & \multicolumn{4}{|c|}{ By Age Categories (yr) } \\
\hline & $<34$ & 35 to 68 & 69 to 201 & $>202$ & 17 to 25 & 26 to 40 & 41 to 55 & $>56$ \\
\hline Consumer & 11.6 & 17.4 & 40.6 & 9.7 & 3 & 25.6 & 31.2 & 31.6 \\
\hline Coffee from beans & 6.5 & 13.8 & 30.1 & 7.3 & 2.1 & 16.4 & 26 & 13 \\
\hline$>1$ cup per day & 4.9 & 12.2 & 35.8 & 9.8 & 0.7 & 20.5 & 29.5 & 11.6 \\
\hline At home/office & 13.8 & 21.1 & 47.1 & 11.4 & 3.4 & 32.2 & 41.1 & 17.1 \\
\hline At traditional coffee shops & 1.6 & 3.3 & 17.9 & 7.3 & 2.1 & 11 & 9.6 & 4.8 \\
\hline At café & 0.8 & 0.8 & 2.4 & 2.4 & 0.5 & 4.1 & 1.4 & 0.7 \\
\hline
\end{tabular}

growing income, and gradually shifting from coffee shops to café to fit their new financial status. The finding is consistent with the documentation that since 2012, the coffee production volume is increasing but the household coffee consumption is decreasing significantly (Center for Agricultural Data and Information Systems 2016). At the same time, the coffee consumption is also increasing (Statista, 2018), while the café business is growing (JPNN, 2016). Therefore, it is suspected that the coffee consuming habit has shifted from home-based to café-based.

\section{DISCUSSION}

\subsection{The patrons and their economy}

Café patrons are mostly people age (25 to 40 ) yr who have personal monthly income above USD 69. The reason for visiting café is recreational and more to affirm their new economic status. However, they are still regular customers of coffee shops because of needs to get quick caffeine on friendly budget and old habit. A stark change is in the intensity and visiting duration to coffee shops. While previously respondents visited coffee shops daily and spent minimum $1 \mathrm{~h}$ on chatting with fellow costumers, now once or twice per week in $30 \mathrm{~min}$ is the average in which they will spend the time for drinking and eating. Respondents visit café once to twice per week and spend approximately $1 \mathrm{~h}$ to $2 \mathrm{~h}$ to chat with friends, reading, working, or surfing the internet.

People under $25 \mathrm{yr}$ and above 41 yr are not regular café patrons due to unfamiliarity with the place. People with income under USD 68 finds café is too expensive but still occasionally visiting café. These groups are the regular customers of coffee shops.

\subsection{The coffee shops}

Coffee-drinking establishment categorization changes following the change in market segmentation. Before 2012, at least, two categories of the establishment existed in towns of Indonesia that are the café-in which the price for a cup of coffee is more than USD 1, and coffee shop-under USD 1 per cup. The café in pre-2012 were mostly connected with hotel or restaurant service and serving full meals; without regular patrons; visited mostly by businessmen as a business meeting place. Other characteristics are: the table arrangement was private seating; serving mass-production (market-available) coffee; some place provided live music as entertainment. The coffee shops were family business that serving sachet and instant coffee; serving the simple meal; supported by regular patrons who were mostly male; served as an informal community center.

Post-2012, the categorizations are growing into three. First, the expensive café-more than USD 3 per cup, the middle range café-one until USD 2 per cup, and coffee shopunder USD 1 per cup. The expensive cafés are connected to global/regional/domestic café chain or boutique café. These cafés care to the quality of the beans; serving light meals and beverages other than coffee, and offer a cozy ambiance with air-conditioned rooms in most of the place. The middle range cafés also pay attention to the quality of coffee but rely on local beans; serving beverages and light meals; the coziness of the rooms also an important matter even though air-conditioned rooms are not mandatory. The post-2012 coffee shops are still similar to the previous era.

Segmentation for coffee business changed in 2012 as a response to the growing economy. Global-brand such as Starbucks and domestic/regional-brands cafés such as Excelso, Maxx Coffee and J.CO started growing in Indonesia. In small towns, the arrival of chain-café $s$ is parallel with the development of shopping malls and business centers as they come as one business package. The high price of the branded café product is irrelevant for the consumers as the brand is the power to win the market. Deloitte (2017) notes $8 \%$ to $17 \%$ of consumers chose more expensive products for beverages due to the trust to the brand. In interviews, café patrons claimed to be more concern to the quality of the coffee, the service provided, the prestige of the brand, and the ambiance of the place, rather than the price, when visiting a café (Susanty; Kenny, 2015).

The ignorance of the consumers to the price of café's coffee signs their growing power in the economy. Indonesian 
middle class' economic capacity has been significantly growing in the last decade as Indonesian's current purchasing power parity is on $63 \%$ of the world's average after the GDP increased gradually from USD 9251.2 in 2012 to USD 11 188.74 in 2017 (Trading Economics 2018). In line with that, Deloitte's study (Deloitte, 2017) found that steady increase of economic power of the middle-class has enabled the growing retail business in Indonesia. Thus, it can be expected that in the café will develop significantly in the coming years in line with the growing economy.

\subsection{Customers' social engagement}

The coffee shop had held influential social function. It was suggested that historically, coffee is more than a beverage as it was a culture and identity for Indonesians through coffee shops visits (Gumulya; Helmi, 2017). The coffee shop was an informal social education center. Customer interaction in coffee shops facilitated by the table arrangement in which all customers share one big table with few benches. Customers interact with each other and welcome to join in free flow discussions, and sometimes formed an informal consensus, on topics of politics, social, and economy. Disagreements between people were also discussed over coffee. Erman (2014) suggest that students use the establishment as an informal venue to learn about politics and other social issues. However, the social function is diminished after the arrival of cafés. To illustrate:

"In the coffee shop, people can discuss with fellow community members and obtain enlightenment on the current issues, such as economic, social, and even to some extent, politics.

For student activists, learning about politics and political movements is more in the coffee shop than on campus. The coffee shop is comfortable, and we can meet anyone casually."

"If people have diverse opinion on social and political issues, people discuss it mainly in the coffee shop. Even though the coffee shop is not as comfortable as café, in the coffee shop, people feel more relaxed because we can discuss it in average (loud) volume. The atmosphere where people may make political conversation freely is rare in the café as it was in the coffee shops."

The economic potency of café business is the pull factor of the café trend. To adapt to the new business trend and attracts customers, café owners change their café by imitating established brands. The changes in the business change the social function of coffee shops (Rahma; Farida; Marifatullah, 2019). Coffee shops owners admit that customers' interaction has been changed following the changing in coffee shops' table arrangement, service, price, and ambiance. Nevertheless, coffee shops' owners expect the change in customers' interaction and see it as a necessity in modern café. The minimum social interaction among the patrons is regarded as a positive factor to keep the calmness of the place. Café attracts customers who find café as a private corner in a public space (Sathish; Venkatesakumar, 2011). In-group interaction, however, is encouraged in small-town cafés because group dynamics boost the purchases. To illustrate:

"The café provides excellent comfort and soft music. We are reluctant to talk in loud volume. Café s are also often used by people to work and write. Lively discussion at the café, as it was in the coffee shops, can disturb the atmosphere of other people who are working."

"People can use café for discussion by renting a particular room. As a result, making discussions at the café tend to be formal with specific participants. Everyone (random people) may not be able to join the chat, the conversation, and the debate freely."

Informants agree that the change of social contact in café is necessary. While their initial attraction to visit café was the curiosity to the foreign way of coffee serving (e.g. Cappuccino, Vietnamese, etc.), the adventure aspect of enjoying coffee from other countries, and the modern image of café; it is the privacy of café that becomes the essential factor after they familiar with the establishment. On the old habit of engaging with fellow customers in coffee shops, most informants suggest that their small circles of friends and smartphone technology with internet have replaced the coffee shops' discussion sessions with random people. So, the growing literacy in technology and the in-group attachment encourage the changing behavior of coffee shops patrons. To illustrate:

"A lot of information about social problems is currently available on smartphones so that almost everyone already has an almost similar knowledge. The discussion at the café is no longer attractive."

"The answers are all available in the smartphone. Café is an alternative place for googling than discussing."

The changing behavior of coffee shops' patrons has encouraged the weakening of social engagement People disengage with each other when activities to facilitate interaction are interrupted. In small-towns of Indonesia, the needs of coffee shops patrons to visit the establishment have shifted from visiting to interact with other community members to visit for recreational purpose and status affirmation. The change in needs alter the behavior and impact the social-bond. Bandura (2016) study of the weakening social-bond in the US found that the factors of the US phenomena are economic pressure and electronic technology (television), among others. In the context of coffee and culture in Indonesia, it is the economic power and technology (smartphone and internet) that causes the disengagement.

\subsection{The impact on coffee business}

Despite its impact on the social-engagement, café in small towns have encouraged the quality of local coffee 
beans and its derived product. Small-town cafés follow the global trend of standardization of coffee beans with its specific categorization of the beans. In some district such as Jember, Bondowoso, Banyuwangi, and Malang, local coffee mercenaries follow the market and educate coffee farmers of the market needs. To boost the production, farmers receive knowledge of the types of coffee to plant (based on local agro-climate), plant maintenance, beans harvesting, beans processing, beans storing, pre-roasting, and marketing management. Small-town cafés also spearhead the promotion of local beans in the higher market through the presentation of the local product in a modern package. Local beans find a broader market, even though traditional coffee serving styles are diminishing.

\section{CONCLUSIONS}

The study shows that current situation of the coffee shop in small towns of developing country is in the shifting phase from traditional coffee shop to modern coffee shop or café caused by the growing economy and the economic potency of the coffee business. In the consumer level, the shifting from coffee shops to café is caused by the shifting of the needs of coffee shops' patrons from finding company and consuming coffee to entertainment experience and economic status affirmation. The growing economy, technology advances, and the attraction of café as a modern establishment are the factors of the changing needs of the costumes. All those changes affect interaction and engagement among coffee shops costumers shows the changing of the coffee culture.

The changing in coffee culture and coffee shops visitation might reflect the change of the social engagement in the society-at-large. It based on the fact that coffee shop had served as the informal community center and informal social learning center by how the establishment encouraged interaction among patrons. After the interaction is limited, the social function of the coffee shop is also diminishing, and the engagement among patrons is decreasing. However, the changing is unavoidable in the age of globalization. Social change in a larger scale as a spill over of globalization in behavior is expected to arrive in developing countries, such as Indonesia. It might include lower interdependence among groups or individual in society and the decreasing of social engagement. The phenomenon of the developing of café business in small towns is signing the weakening of social engagement in the society.

This research may attract further investigation, such as the economic and social aspects of café in affecting social engagement in small towns. Study on how gender issues matter in cafe plantation and coffee industry are among the works that need to explore. In the context of the cafe, the gender aspect of visiting café, gender-based and local-based preferences on flavor, and presenting coffee is also essential. Other research may relate to how the local coffee and the side product struggles to survive in the wave of global culture and global issues. In the contemporary turbulence of the global pandemic, a study of coffee and the side products for health is also very much relevant.

\section{REFERENCES}

BANDURA, A. Moral disengagement: How people do harm and live with themselves. New York: Worth Publishers. 2016. 544p.

BLOOR, M.; WOOD, F. Keywords in qualitative methods: A vocabulary of research concepts. London: Sage Publications. 2006. 195p.

BROADWAY, M.; LEGG, R.; BROADWAY, J. Coffee houses and the art of social engagement: An analysis of portland coffeehouses. Geographical Review, 108(3):433-456, 2018.

DELOITTE. Deloitte consumer insights embracing bricks and clicks in Indonesia Jakarta: Deloitte Southeast Asia Ltd. 2017. 35p.

CECILIA, A. et al. Collectrichum on coffee trees in south of Minas Gerais-Brasil: Physiological, molecular and pathogenic description. Coffee Science, 11(4):444-454, 2016.

\section{CENTER FOR AGRICULTURAL DATA AND} INFORMATION SYSTEMS. Outlook kopi [Coffee outlook]. Jakarta: Center for Agricultural Data and Information Systems Secretariat General, Ministry of Agriculture Indonesia, 2016.

DAMAT, D. et al. Dietary fiber and antioxidant activity of gluten-free cookies with coffee cherry flour addition. Coffee Science, 14(4):493-500, 2019.

DEWANTI, I. D. A. R. et al. The effect of steeping Robusta coffee beans on monocytes: Expression of IL-1 $\beta$ and TNF- $\alpha$ against Streptococcus mutans. Coffee Science, 14(4):477-483, 2019.

ERMAN, E. Dinamika komunitas warung kopi dan politik resistensi di Pulau Belitung. [The dynamics of coffee shop community and resistance politics on Belitung Island]. Masyarakat Indonesia, 40(1):89$107,2014$.

ESQUIVELA, P.; JIMENEZB, V. M. Functional properties of coffee and coffee by-products. Food Research International, 46(2):488-495, 2012. 
FERREIRA. J. Cafe nation? Exploring the growth of the UK café industry. Area, 49(1):69-76, 2017.

GUMULYA, D.; HELMI, I. S. Kajian budaya minum kopi Indonesia. [Study of Indonesian coffee drinking culture]. Jurnal Dimensi Seni Rupa dan Desain, 13(2):153-172, 2017.

HENRIKSEN, I. M.; SKJØLSVOLD, T. M.; GRØNNING, I. The café community. In: TJORA, A.; SCAMBLER, G. (Eds.). Café society. New York: Palgrave Macmillan. 2013. p.87-101.

HEEGER, A. et al. Bioactives of coffee cherry pulp and its utilisation for production of cascara beverage. Food Chemistry, 221:969-975, 2017.

JPNN. Potensi bisnis kafe sentuh USD 4.16 miliar. Cafe business potential touches USD 4.16 billion. 2016. Available in: $<$ https://www.jpnn.com/news/potensi-bisniskafe-sentuh-usd-416-miliar>. Access in: August, 23, 2017.

RAHMA, A.; FARIDA, I.; MARIFATULLAH, A. Knowledge sharing over coffee: A history-based community in urban Jakarta. Advances in Social Science, Education and Humanities Research, 302:109-113, 2019.

SATHISH, A. S.; VENKATESAKUMAR, R. Coffee experience and drivers of satisfaction, loyalty in a coffee outlet-with special reference to "café coffee day".
Journal of Contemporary Management Research, 5(2):1-13, 2011.

STATISTA. Total coffee consumption in Indonesia from 1990 to 2017 (in 1,000 bags*) 2018. Available in: $<$ https://www.statista.com/statistics/314982/indonesiatotal-coffee-consumption/>. Access in: August, 15, 2018.

SUSANTY, A.; KENNY, E. The relationship between brand equity, customer satisfaction, and brand loyalty on coffee shop: Study of Excelso and Starbucks. ASEAN Marketing Journal, 7(1):14-27, 2015.

SUTTON, J.; AUSTIN, Z. Qualitative research: Data collection, analysis, and management. The Canadian Journal of Hospital and Pharmacy, 68(3):226-231, 2015.

TOROK, A.; MIZIK, T.; JAMBOR, A. The competitiveness of global coffee trade. International Journal of Economics and Financial Issues, 8(5):1-6, 2018.

TRADING ECONOMICS. Indonesia GDP per capita PPP 1990-2018. Available in: $<$ https://tradingeconomics.com/ indonesia/gdp-per-capita-ppp>. Access in: July, 28, 2018.

VIGNOLI, J. A.; BASSOLI, D. G.; BENASSI, M. T. Antioxidant activity, polyphenols, caffeine and melanoidins in soluble coffee: The influence of processing conditions and raw material. Food Chemistry, 124(3):863-868, 2011. 